\title{
From our own correspondents
}

The beginning of a new year, a new decade — or even a new millennium — is a time for analysis and prognosis. On the next five pages, Nature's senior news correspondents reflect on their experiences in reporting from different parts of the world during the past decade. To these recollections, they add thoughts about the current state of play between science and society across the world, and brief personal reflections on how this relationship is likely to develop in the years ahead.

\section{'US politicians have fallen in love with basic research'}

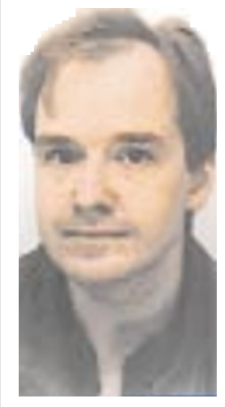

Colin Macilwain is the senior US corresponent for Nature, and has been based in Washington since 1993.

\section{Washington}

A picture of America that sticks in my mind, after seven years of covering US science policy from Washington, is of a plateau in southern Idaho. I was approaching the Argonne West laboratory, on a visit in the summer of 1993.

The outlook was strikingly similar to Rannoch Moor in the highlands of my native Scotland. Except that the tiny white specks dotted across the landscape were not isolated crofts, but more than 50 experimental nuclear reactors constructed, and in most cases discarded, during the Cold War

The sheer scale of the Idaho National Engineering and Environmental Laboratory - a somewhat artificial entity dreamt up by Washington bureaucrats to manage and clean up these reactors - would overwhelm any visitor recently arrived from Europe, where nuclear technology has been developed in relatively cramped conditions.

The geographical, technical, human and financial resources available to the United States when it developed the atomic bomb, and still available to it today, struck home with me on that summers' day in Idaho.

And the sight of a vast convoy of cars and yellow buses crawling across the moor, returning thousands of laboratory workers to their Idaho City homes at four o'clock on a Friday afternoon, made a similarly lasting impression.

Every state in the union gets its share of the United States' technical and budgetary largesse, thanks chiefly to the composition of the US Senate, which has two powerful senators for each state, large or small (try that in
Europe, and see what it does for science in Ireland or Portugal). In the case of Idaho (population 1 million) half a billion dollars and ten thousand well-paid jobs, watching over part of America's nuclear legacy, will do nicely.

When Ted Steven (Republican, Alaska) took over from Mark Hatfield (Republican, Pennsylvania) - a strong ally of biomedical research - as chairman of the Senate Appropriations Committee, a concerned friend of the National Institutes of Health fretted that Alaska didn't have single medical school of note. "It will have soon!" retorted a more optimistic colleague.

For, although everyone is in favour of funding 'the best science', the fact of the matter is that the much-maligned pork-barrel politics is fundamental to the breadth of excellence and opportunity that characterizes the US research system.

\section{Changing the guard}

That system distributes and nurtures excellence through a peculiar mixture of honest peer-review and crude political powerbroking, administered through a fairly chaotic network of rival agencies.

Unlike the more bureaucratic systems of Europe and Japan, the system allows for projects with which the Congress loses patience to be speedily abandoned — including umpteen of the Idaho research reactors and, more famously, the Superconducting Super Collider, whose death in 1993 remains the defining moment in US research policy over the past decade.

The significance of that decision lay chiefly in its psychological impact on the nation's physicists, whose position as the élite cadre of researchers had already been undermined by the passing of the Cold War. The 1990s has witnessed a changing of the guard, and the emergence of a new élite of life scientists, whose probing of the nature of life

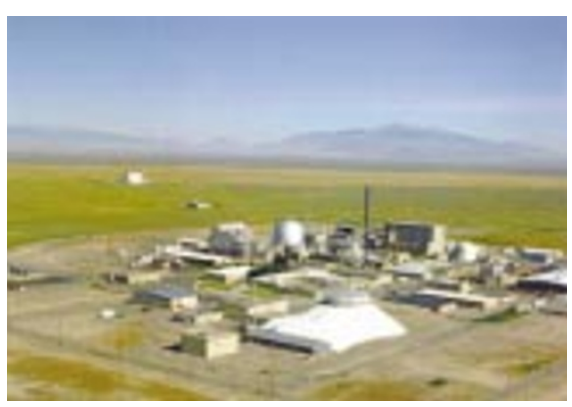

Roll out the pork barrel: federal largesse gave Idaho the Argonne National Laboratory-West.

captivates a public now less than entranced by further exploration the atom.

Their new pre-eminence will be confirmed when a future president of the United States appoints a biologist as his or her science advisor, a position that has always been held by a physicist. The job's importance seems to have diminished in recent years which is odd, given that US politicians and their advisers have newly fallen in love with basic scientific research.

Bill Clinton came into office in 1993 insisting that technology - as opposed to science - could revive America. The aura of Japan's Ministry of International Trade and Industry was still intact at the time, and he proposed pouring billions of dollars into technology programmes intended to revitalize American industry. Eight years later, US industry has revived itself, and conventional wisdom holds that the United States' lead in basic science has contributed greatly to the current economic boom.

\section{Crawling towards 2000}

But the new conventional wisdom may have limited currency. Many of the most successful 'high-technology' businesses, ranging from America Online to the strange collection of wannabe Internet retailers whose television advertising has dominated the airwaves in the run-up to the holidays, have little to do with either science or technology.

These peculiar television ads, alternating with equally desperate news bulletins warning the American population of hypothetical millennial terrorist threats, provide an unap- 
pealing background noise for the greatest power the world has ever seen, as it crawls furtively into the year 2000 .

It was ever thus: as Harold Evans, the English journalist, points out in a recent edition of US News and World Report, similar apprehensions were widely expressed at the dawn of what turned out to be the American Century. For that we should perhaps be grateful. Despite the opposite impression prevalent overseas, a general absence of hubris is one of America's abiding strengths.

To give one tiny example, Americans from talkshow host Jay Leno down - believe that their schools don't work, partly on account of the widely publicized Third International Mathematics and Science Study, published in 1998. Yet Jon Miller of the

Chicago Academy of Sciences has shown that US adult understanding of science is among the very highest in the world, owing to the enormous number of Americans who learn more science at college.

Of course, this doesn't mean that sound science steers US public policy. Take global warming: seven years of data, not to mention generally mild weather, have made no impression whatsoever on Congress's obstinate refusal to face the problem.

The United States, in that time, has come a long way towards recognizing the interplay between science and the economy. It is accepted that science can help to make the country both rich and healthy. Whether it can also make it more enlightened is an open question.

Colin Macilwain

\section{'The role of science is to illuminate political choices, not enforce them'}

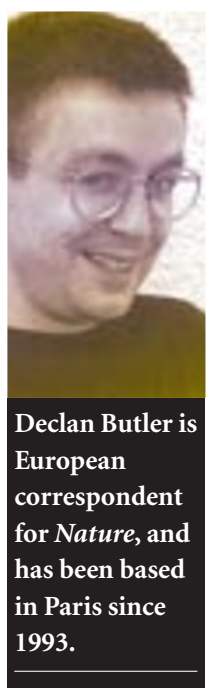

\section{Paris}

"I must reveal that in an earlier incarnation many years ago, I earned my living by writing for Nature, the world's most venerable scientific journal", wrote the anonymous columnist 'Bagehot' in May. He was delivering a typically provocative and pertinent analysis in The Economist on the British government's regulation of genetically modified organisms (GMOs).

The experience, he continued, "gave me a damaging regard for scientists", and he concluded that "simply quoting scientific authority is no answer to the conundrum of public trust". Rather, this could only be achieved by transparent, impartial decision making based on wide consultation.

After eight years of writing for this venerable journal, I do not have a damaging regard for scientists, far from it. But a recurring theme of my experience of reporting on issues such as France's blood scandals, human cloning, bovine spongiform encephalopathy (BSE), xenotransplantation and GMOs, is that the role of science - with all its attendant uncertainties - must be to illuminate political choices, not enforce them.

The risk of over-dependence on experts has been illustrated ad nauseam in our news pages. An epidemic of Creutzfeldt-Jakob disease of unknown proportions is hanging over the United Kingdom and the many other countries whose citizens ate British beef contaminated with the agent that causes BSE.

People throughout the world have been infected with HIV by transfusions of contaminated blood in the mid-1980s. In both cases, experts were not only fallible, but were all too often swayed by economic and political considerations.

\section{Backlash}

The backlash against experts has been most dramatic in France, where several individuals have been sent to prison in connection with contaminated blood supplies. Britain has taken a more dispassionate stance on its BSE crisis, convening a long and thorough $\mathfrak{E} 16$ million (US\$26 million) inquiry to determine eventual responsibility. The inquiry's conclusions are likely to reinforce Winston Churchill's maxim that "scientists should be on tap, not on top".

But these backlashes are part of a wider change. We are in the middle of a profound and irreversible restructuring in the contract between scientists and society that has been in place since the Second World War (see Nature 402 supp, C81; 1999). That is why it is telling that even The Economist, the most influential mouthpiece for free trade and technological progress, acknowledges the need for a redefinition of the limits of scientific authority.

For one thing, under international trade law, any country refusing to import a product on safety grounds must justify its action. But a compromise now seems inevitable between free trade and demands to refuse imports on the basis of scientific uncertainty - such as the European Union's rejection of US hormone-treated beef, or France's refusal to respect the lifting of the European embargo on British beef.

Yet the phenomenon of 'globalization' has been ignored too long in such debates. Classical risk-assessment procedures, for example, largely fail to take into account the speed and scale with which new technologies are introduced worldwide the relatively new risk is that if something goes wrong, it will go wrong in a big way.

Debates over GMOs and xenotransplantation show that, ultimately, the public's acceptance of new technology has less to do with science than with an

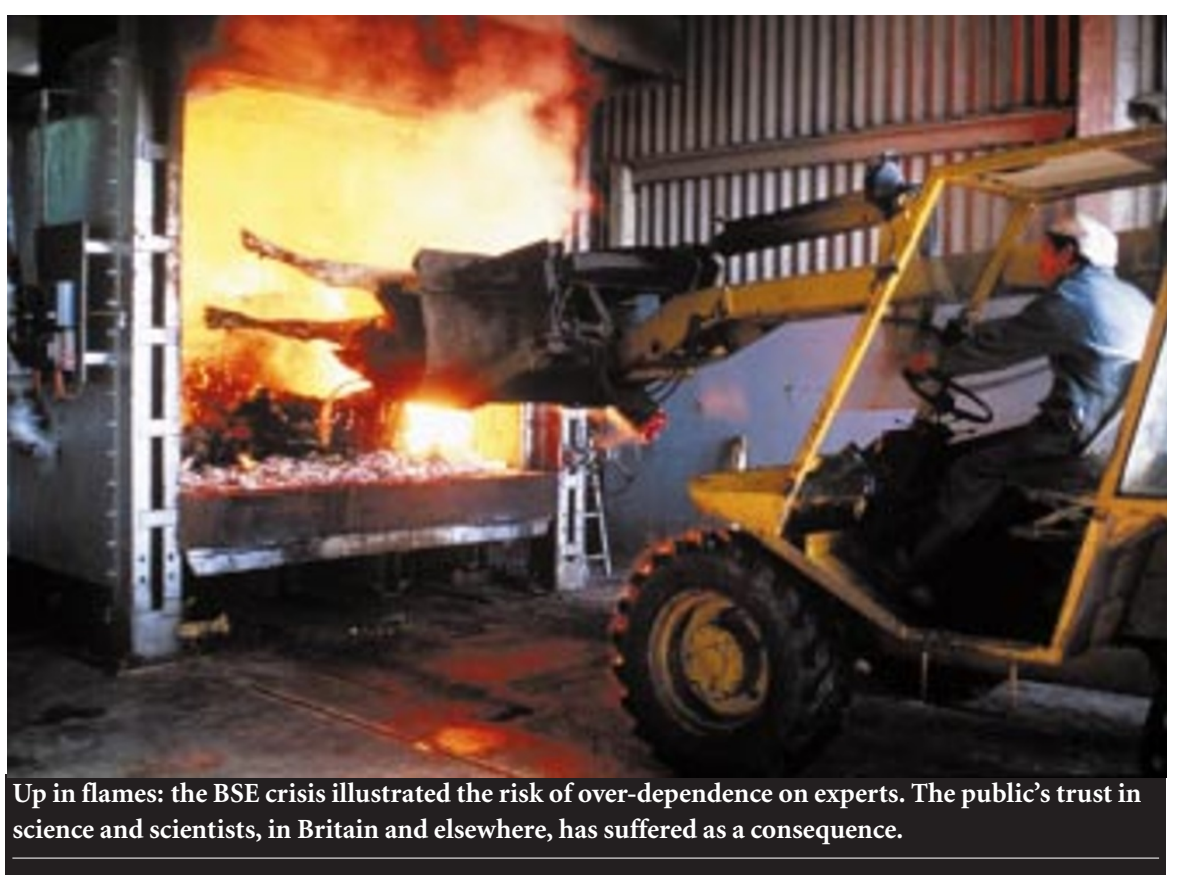

